\title{
LAKOFF VE JOHNSON'IN METAFOR KURAMI VE ESKİ TÜRKÇE İLE ORTA TÜRKÇEDE BİRLEŞİK FIIILLERDE YÜK METAFORU
}

\author{
LAKOFF AND JOHNSON'S THEORY OF METAPHOR AND \\ BURDEN METAPHOR IN COMPOUND VERBS IN OLD TURKISH \\ AND MIDDLE TURKISH
}

Timur AYDIN*

\begin{abstract}
$\ddot{O} z$
G. Lakoff ve M. Johnson'in metafor kuramı, metaforun yalnızca bir edebî sanat olmayıp algı ve davranışlar üzerinde etkisi olan bir psikolojik ve bilişsel mekanizma olduğunu göstermektedir. Bu çalışmanın ilk kısmında Lakoff ve Johnson'ın metafor kuramına değinilmekte, onların İngilizce için verdikleri bazı metafor örneklerinin Türkçedeki mukabillerinden bahsedilmektedir. Çalışmanın ikinci kısmında; Eski ve Orta Türkçede tüşür-, kir- kötür-, yüd-, tart-, çek- fiilleriyle kurulan birleşik fiillerde artzamanl olarak yük metaforunun izi sürülmekte, çek- ve tart- fiilleriyle kurulan birleşik fiiller Farsça mukabilleriyle karşılaştırılmaktadır

Anahtar Kelimeler

Metafor, George Lakoff, Mark Johnson, birleşik fiil.

Abstract

G. Lakoff's and M. Johnson's theory of metaphor demonstrates that metaphor is not an only figure of speech, also a psychological and cognitive mechanism has an impact on perception and behavior. In the first chapter of this study; Lakoff's and Johnson's theory of metaphor and Turkish equivalents of their metaphor examples which they gave for English are mentioned. In the second chapter of this study; burden metaphor is diachronically traced in compound verbs which are established with tüşür-, kir-, kötür-, yüd-, tart-, çek- in the Old and Middle Turkish and compound verbs which are established with çek-, tart- are compared with Persian equivalents.
\end{abstract}

Keywords

Metaphor, George Lakoff, Mark Johnson, compound verb.

Arş. Gör., Gelişim Üniversitesi Türk Dili ve Edebiyatı bölümü, timurayd@gmail.com. 


\section{Lakoff ve Johnson'in Metafor Kurami ${ }^{1}$}

İstiare yahut metafor², belagatin ilm-i beyân şubesi içerisinde ele alınan bir edebî sanattır. "Bir lafza aralarındaki benzerlik alakası dolayısıyla lügat manasının dışında yeni bir mana vermek" olarak tanımlanmaktadır (Saraç 2000: 98). Mesela bir askere aslanım denilebilir. Asker, aslan gibi cesurdur ve bu benzerlik alakası dolayısıyla aslan kelimesine yeni bir mana, asker manası verilmiştir (Olgun 1936: 54). Şüphesiz aslanla kastedilen biyolojik taksonomide panthera cinsine dahil edilen yırtıcı hayvan panthera leo değildir. Metafor gerek edebî metinlerde gerekse yukarıdaki örnekteki gibi gündelik hayatta karşılaştığımız bir edebî sanat olmasının yanı sıra psikolojik ve bilişsel bir mekanizmadır ${ }^{3}$. Edebî sanatların bu cephesine daha önceden değinenler olmuştur. Mesela Ali Nihat Tarlan, edebiyatı da kapsadığını söylediği estetik faaliyetlerin kanunlarının psikolojik bir ciheti olduğunu belirtmektedir. Ona göre her edebi sanat doğuşu bakımından bir ruhî ihtiyacın mahsulüdür (Tarlan 1947: 13). Walter Andrews da edebî sanatların eşyayı algılama biçimimizle bir ilgisi olduğundan bahsetmiş, ancak bunun araştırılmasının alan dışı bir uzmanlık gerektirdiğini vurgulamıştır. Dolayısıyla Ockhamlı'nın usturası bu konuya vurulmalı ve edebî sanatların araştırılması edebiyatla sınırlandırılmalıdır (Andrews 1976: 78). Halbuki Andrews'un kitabının neşredildiği tarihten dört sene sonra edebi sanatlar ve psikoloji ilişkisine değinen Lakoff ve Johnson edebî sanatlardan biri olan metafor çalışmalarına yeni bir boyut kazandırmıştır.

Lakoff ve Johnson, gündelik dili kuşatan bir metafor sistemi olduğunu iddia eder. $\mathrm{Bu}$ durum yalnızca dille alakalı da değil, insan zihninin dünyayı nasıl algıladığıyla alakalıdır. Metafor insanın dünyayı algılamasını şekillendirmektedir (Lakoff \& Johnson 1980: 3) Metaforun algıyı nasıl şekillendirdiğini daha iyi anlamak için Türkçedeki TARTIŞMA SAVAŞTIR ${ }^{4}$ metaforuna bak1labilir5:

Türkçede Lakoff ve Johnson'ın metafor kuramından yola çıkılarak hazırlanmış çalışmalar mevcuttur. Mesela bkz. ONAY, E. (2013), 15. Yüzyıldan 18. Yüzyıla Kasidelerde İdeal Hükümdar Portresi ve Hükümdarın Metaforik Sunumu, Ankara: Bilkent Üniversitesi, Yayımlanmamış Yüksek Lisans Tezi ve YUNUSOĞLU, M. K. (2016), Budist Türk Çevresi Eserlerde Metaforlar, Ankara: Türk Dil Kurumu Yayınları. Ayrıca dünyada ve Türkiye'de metafor çalışmaları için bkz. YUNUSOĞLU, M. K. (2016), 1.8. Metafor Üzerine Çalışmalar, ss. 44-46.

2 Metafor ve istiarenin aynı şey olup olmadığı tartışmalıdır. Mesela metafor ile istiare arasındaki farkın Batı düşüncesi ile Doğu düşüncesi arasındaki farklılıktan kaynaklandığı söylenmiştir (Demir 2005: 14). Ben istiare yahut metaforun insan zihninin temel bir psikolojik mekanizması olduğu, dolayısıyla evrensel bir karakteristik taşıdığı kanaatindeyim; ancak bu düşünce burada kanıtlanmaya çalışılmayacak, metafor ve istiarenin aynı şey olduğu farz edilecektir. Bu konu başlı başına bir araştırma konusu olacak kadar teferruatlı görünmektedir.

3 Metaforun bu cephesine değinen çalışmalar mevcuttur. Mesela bkz. CAVE T. (2016), "Cognitive Figures”, Thinking with Literature: Towards a Cognitive Criticism içinde, Oxford: Oxford University Press ve BOWES A. \& KATZ A. (2015), "Metaphor creates intimacy and temporarily enhances theory of mind", Memory \& Cognition, 43 (6).

4 Bu metafor, aynı zamanda İngilizcede de bulunmaktadır. Lakoff ve Johnson şu örnekleri verir (Lakoff \& Johnson 1980: 4): Your claims are indefensible. He attacked every weak point in my argument. His criticisms were right on target. I demolished his argument. I've never won an argument with him. You disagree? Okay, shoot! If you use that strategy, he'll wipe you out. He shot down all of my arguments.

5 Örnekler için Lakoff ve Johnson'ın eserinin Türkçe çevirisinden faydalanılmıştır (Demir 2005). Ancak çeviride pek çok örneğin Türkçenin mantı̆̆ıyla ve metafor sistemiyle örtüşmeden kullanıldığı görülmektedir. Bu yüzden Türkçe çevirideki örnekler Türkçe'nin mantığına ve metafor sistemine göre tadil edilip kullanılmaya çalışılmış, bazı yerlerde çeviriden tamamen bağımsız örnekler bulunmuştur. 
TARTIŞMA SAVAŞTIR: Hiçbir temele dayanmayan bu iddiayı nasıl savunursun, anlamıyorum. Bütün entelektüel dikkatini toplayarak sıralanan iddialara saldırmaya başladı. Eleştirilerini doğru hedefe yönelttiğini düşünmüyorum. Bu teoriyi yıkmak neredeyse imkânsız. Bugüne kadar girdiği hiçbir tartışmada mă̆lup olmadr. Tartışmadan galip çıksa da saldırgan tavrı yüzünden itibarı zedelenmişti.

Savunmak, saldırmak, hedefe yöneltmek, yıkmak, mağlup olmak, galip çıkmak ve saldırganlık esasında savaş esnasında tarafların tecrübe edeceği durumlardır. Birlik, bir hücuma karşı mevkiini savunabilir. Türkçedeki TARTIŞMA SAVAŞTIR metaforu tıpkı orduların mevkiini savunması gibi, iddiaların da savunulabileceğini varsaymaktadır. Bir birlik, taarruza geçip düşman hatlarına saldırabilir. Bir tartışmada da sanki düşman hatlarına saldırıyormuşçasına iddialara saldırmanın mümkün olduğu görülmektedir. Bir kruvazör toplarını düşman mevziilerine çevirebilir, yani hedefe yöneltebilir. Benzer şekilde gündelik dil, eleştirilerin de bir silah gibi hedefe yöneltilebileceğini söylemektedir. Gündelik dil sayesinde düşman kalesini yıkıyormuş gibi teorileri yıkmak, savaştan galip yahut mağlup ayrılıyormuş gibi tartışmadan galip yahut mă̆lup ayrılmak mümkündür.

Metafor bir kavramın, başka bir kavram vasıtasıyla açıklanmasını ve tecrübe edilmesini sağlar. Yukarıdaki kullanımlarda tartışma, savaş vasıtasıyla anlaşılmakta ve tecrübe edilmektedir. Savaşla ilgili unsurlar tartışmaya da aktarılmakta ve bu durum dile yansımaktadır. Eğer tartışmanın savaş olarak değil de dans olarak algılandığı bir kültür mevcut olsaydı, o kültürün dili de bambaşka olacaktı. Tartışmacılar dans edip durumdan keyif alan kimseler olarak tasvir edilecek, maksat galip gelmek değil, süreçten estetik haz almak olacaktı; ancak kültürümüzde tartışma savaş metaforuyla çerçevelendiği için, belki bu kültürün tartışmadan anladığı şey, bizim için tartışma bile sayılmayacaktı (Lakoff \& Johnson 1980: 5).

Tartışma kavramının savaş metaforuyla çerçevelenmiş olması gibi, zaman metaforunun Türkçede parayla çerçevelenmiş olduğu görülür:

ZAMAN PARADIR6: Lütfen zamanıı bu boş işlere harcama. Kendimden başka kimseye vakit harcamak istemiyorum. Makalemi yeniden düzenlemek bana $\ddot{u}$ şaate mâl oldu. Zamanını daha verimli kullanmak senin elinde. Bu işle uğraşırken çok zaman kaybettim.

Bu metafor sebebiyle para harcar gibi zamanı ve vakti harcamaktan, bir metanın bize belli miktar bir paraya mâl olması gibi, bir işin belli miktar bir zamana mâl olmasından, tıpkı parayı verimli kullanır gibi zamanı verimli kullanmaktan, parayı boş yere harcayıp kaybetmekten söz eder gibi zaman kaybetmekten bahsedilmektedir. Metaforik kavramsal çerçevenin bir özelliği de bir kavramı başka bir kavramla algılar ve o ikinci kavramın cephesinden görürken, görülebilecek diğer cepheleri karanlıkta bırakmasıdır (Lakoff \& Johnson 1980: 10). Zamanı, para cephesiyle algılar ve görürken yakın bir arkadaşla geçirilebilecek keyifli bir süreyi boşa harcanan zaman, bir işe keyifle çalışıp zevk alınabilecek süreyi vakit kaybı saymak mümkündür. Aynı şekilde tartışmayı savaş metaforuyla algılamak, tartışmanın işbirliğine ve uzlaşmaya yönelik cephelerini göz ardı etmekle ve yalnızca galip gelmeye odaklanmakla sonuçlanabilir.

İngilizce'de de mevcuttur (Lakoff \& Johnson 1980: 8): I don't have the time to give you. How do you spend your time these days? That flat tire cost me an hour. I've invested a lot of time in her. I don't have enough time to spare for that. You're running out of time. You need to budget your time. Put aside some time for ping pong. Is that worth your while? Do you have much time left? He's living on borrowed time. You don't use your time profitably. I lost a lot of time when I got sick. Thank you for your time. 
Her kavramın tek bir metaforla çerçevelendiğini söylemek imkânsızdır. Çoğu zaman bir kavram birden fazla kavramla metaforik olarak ifade edilebilir. DÜŞÜNCELER/DÜŞÜNCE SISTEMLERI BINADIR ve DÜŞÜNCELER/DÜŞÜNCE SISTEMLERİ İNSANDIR metaforları buna örnektir:

DÜŞÜNCELER/DÜŞÜNCE SİSTEMLERİ BİNADIR7: Fikirleri ilginç olabilir, ama temelleri sağlam gözükmüyor. Dinin temelinin namaz olduğunu çocuklar bile bilir. Sosyal Darvinizm faşizmin temeli olmuş, sonrasındaysa gürültülü bir şekilde çökmüştür. Namaz dinin temeliyse oruç onun direğidir. Teoriyi destekliyorum; ama bu bazı cephelerden sorunlu olduğu gerçeğini değiştirmiyor. Aslı astarı olmayan, hiçbir esasa dayanmayan fikirleri savunmaya ne de meraklısın! Önce fikirlerini bir temele dayandırıp sonra yayımlamaya çalışmanı öneririm.

DÜŞÜNCELER/DÜŞÜNCE SISTEMLERI İNSANDIR ${ }^{8}$ : Rölativite teorisi fizikte çok sayıda yeni düşünce doğurdu. Robert Trivers'ın modern biyolojinin babası olduğunu söylemek yanlış olmaz. Bu düşünceler Orta Çağ'da öldü. Düşünceleri sonsuza dek yaşayacak. Bilişsel psikoloji henüz emekleme döneminde.

Düşünceleri, düşünce sistemlerini bina ve insan olarak algılamanın yaratacağı farklı farklı durumlar olacaktır. Düşünceleri bina vasıtasıyla anlamak, onların kompleks mimari yapısını, yani sistemli, düzenli şekilde bir araya getirilmiş, üzerlerine itinayla düşünülmüş olmasını vurgulamaktadır. Düşünceleri insan vasıtasıyla anlamak ise onların tıpkı insan gibi her an değiştiğine, yaşayıp öldüğüne, yani ortaya çıkıp ortadan kalktığına, başka düşünceleri doğurduğuna, yani başka düşüncelerin üretilmesine sebep olduğuna vurgu yapmaktadır. Bir metafor düşüncenin sistematik ve düzenli olmasını, diğeri dinamikliğini ve değişkenliğini işaret etmektedir. Böylece aynı kavramın farklı iki cephesi aydınlanmış olmaktadır.

Dünyanın metaforik şekilde algılanmasının altında pek çok kavramın sınırlarının belirsiz ve muğlak olması yatar. Muğlak ve sınırları belirsiz kavramları, hatları daha net kavramlarla açılamak onların anlaşılması adına kolaylık sağlamaktadır (Lakoff \& Johnson 1980: 115). İnsan zihninin çalışma sistematiğiyle ilgili olan bu durum daha net şekilde ANLAMAK GÖRMEKTİR metaforuyla anlaşılabilir:

ANLAMAK GÖRMEKTIR9: Benim bakış açımdan mesele tamamen farklı görünüyor.

Bu konu hakkındaki genel görüşün nedir? Bu kadar kısa bir sürede dünya görüşünün

o denli değişmesine hâlâ şaşıyorum. Konuya neden farklı bir açıdan bakmayı denemiyorsun? Aslına bakarsan hiç de onun gibi düşünmüyorum. Belli bir alanda

\footnotetext{
İngilizce'de de görülmektedir (Lakoff \& Johnson 1980: 46): Is that the foundation for your theory? The theory needs more support. The argument is shaky. We need some more facts or the argument will fall apart. We need to construct a strong argument for that. I haven't figured out yet what the form of the argument will be. Here are some more facts to shore up the theory. We need to buttress the theory with solid arguments. The theory will stand or fall on the strength of that argument. The argument collapsed. They exploded his latest theory. We will show that theory to be without foundation. So far we have put together only the framework of the theory.

8 İngilizce örnekler şöyledir (Lakoff \& Johnson 1980: 47): The theory of relativity gave birth to an enourmous number of ideas in physics. He is the father of modern biology. Whose brainchild was that? Look at what his ideas have spawned. Those ideas died off in the Middle Ages. His ideas will live on forever. Cognitive psychology is still in its infancy. That's an idea that ought to be resurrected. Where'd you dig up that idea? He breathed new life into that idea.

9 İngiliz dilinde de görülen bir metafordur (Lakoff \& Johnson 1980: 48): I see what you're saying. It looks different from my point of view. What is your outlook on that? I view it differently. Now I've got the whole picture. Let me point something out to you. That's an insightful idea. That was a brilliant remark. The argument is clear. It was a murky discussion. Could you elucidate your remarks? It's a transparent argument. The discussion was opaque.
} 
uzmanlaşma o alanı hakkıyla bilme gibi bir artı yanında başka alanlara at gözlüğüyle bakmak gibi bir eksi getirebilir. Boş boş bakmayı bırak da anlamaya çalış! Esere bir de bu gözle bakmayı denemelisin. Yaşına başına bakmadan neler yapıyor, neler!

Bir nesneyi sınırlı bir uzay içerisinde görmek, onun diğer nesnelerle ilişkisini belirlemek, diğer nesnelere uzaklığını tespit etmek, ona farklı yerlerden bakarak niteliklerini daha iyi görmek, şüphesiz fikrî ve zihnî bir durumu anlamaya göre daha basittir. Fikrî ve zihnî bir durumu anlamak, görmek metaforuyla açılandığında sanki anlaşılmaya çalışılan konu, bakış açısındaki bir nesneymiş gibi algılanmakta, onun değişik veçhelerine farklı açılardan bakmak mümkün olmaktadır. Böylece muğlak ve sınırları belirsiz anlamak kavramı, görmek kavramının belirli ve sınırlı yapısıyla açıklanmaktadır.

\section{Eski Türkçe ve Orta Türkçede Birleşik Fiillerde Yük Metaforu}

Türkçede; birleşik fiillerin, bilhassa anlamca kaynaşmış ve deyimleşmiş birleşik fiillerin Lakoff ve Johnson'ın metafor kuramıyla yakından bir ilgisi olduğu düşünülebilir. Mesela derdini aç-, duygularını aç-, ruhunu aç-, yüreğini aç- birleşik fiillerinin ardında DUYGU VE DÜŞÜNCELER KAPALI BİR NESNEDİR; işi geoşek tut-, sıkı çalış- birleşik fiillerinin ardında CIDDIYET SIKI, CIDDIYYETSIZLIKK GEVŞEKTIR; aklından çıkar-, hatırından çıar- birleşik fiillerinin ardında AKIL MEKÂNDIR metaforlarının yattığı sezilir. Ayrıca; M. Kemal Yunusoğlu, Budist Türk çevresi eserlerde metaforlar üzerine odaklandığı çalışmasında, Türkçe deyimlerin Lakoff ve Johnson'ın metafor kuramıla ilişkisinden bahsetmiştir. O, Eski Uygurca

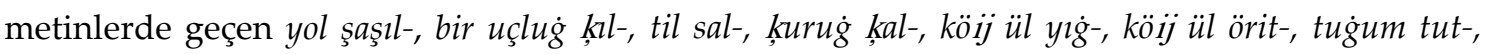
köij ülinte yügerü bol- gibi anlamca kaynaşmış ve deyimleşmiş birleşik fiillerin metaforik yapısına değinir (Yunusoğlu 2016: 137-140). Lakoff ve Johnson'ın kuramından hareketle anlamca kaynaşmış ve deyimleşmiş birleşik fiilleri kuşatan metaforik çerçeveyi artzamanlı olarak tahlil etmek, bu metaforik yapının nasıl ortaya çıktığını araştırmak uzun bir araştırmanın konusu olabilir. Bu sebeple anlamca kaynaşmış ve deyimleşmiş birleşik fiillerdeki metaforik yapıyı artzamanlı olarak incelemek için başlangıçta tek bir örnek üzerinde durmak faydalı olacaktır. Bu maksatla, çalışmanın ilerleyen kısmında Eski ve Orta Türkçede OLUMSUZ DUYGU veya DURUMLAR YÜKTÜR metaforu, birleşik fiiller üzerinden incelenecektir.

Türkiye Türkçesindeki acemilik çek-, acı çek-, azap çek-, cefa çek-, çile çek-, derdini çek-, eziyet çek-, güçlük çek-, hastalık çek-, ızdırap çek-, kahrını çek-, nazını çek-, sıkıntı çek-, zahmet çek- gibi pek çok örneği bulunan OLUMSUZ DUYGU veya DURUM + ÇEK- (O.D.D. + çek-) yapısındaki birleşik fiillere dikkatli bakılırsa, bu yapının ardında OLUMSUZ DUYGU veya DURUMLAR YÜKTÜR metaforunun yattığı anlaşılır. Örneklerdeki çek- fiili, kelimenin daha sık kullanılan "(Bir şeyi bulunduğu yerden) kendine doğru getirmek, yaklaştırmak”, “(Bir şeyi) sürüklemek”, “(Bir şeyi bir yerden yahut bulunduğu diğer şeyler arasından) çıkarmak" gibi anlamlarıyla düşünüldüğünde azap çek-, sıkıntı çek-, zahmet çek-, gibi birleşik fiiller bir anlam ifade etmemektedir. Bu yapıdaki birleşik fiillerde, çek- fiili çeki "1. 250 kiloluk ağırlık ölçüsü, 2. Tartı" kelimesinde ve Yük üç yüz kilo çekti cümlesindeki gibi "tartmak" ve dolayısıyla "yüklemek, yüklenmek" manasında kullanılmaktadır ${ }^{10}$. Böylece, sıkıntı, acı, zahmet gibi olumsuz duygu ve durumlar, yük kavramıla algılanmaktadır.

10 Kâmûs-1 Türkî'de de çekmek maddesinde "terazi ve kantar ile tartmak" anlamı yer almakta, akabinde "Şu çuvalı çek bakalım kaç okkadır” örneği verilmektedir (Akün 1998: 513c). Fiilin bu kullanımı, onun "yüklenmek” anlamını açığa çıkarmaktadır. 
Yük metaforu, artzamanlı olarak incelendiğinde, Türkçenin belli bir tarihî devrinden, Karahanlıcadan sonra bu metaforun ilgili birleşik fiillerle kullanılmaya başlandığ görülür. Karahanlıca devri dahil olmak üzere, Köktürkçe ve Eski Uygurca metinlere bakıldığında; O.D.D. + tüşür-, O.D.D.+DA + ara kir-, O.D.D. + kötür-, O.D.D. + yüd- yapısındaki birleşik fiillerin tıpkı Türkiye Türkçesindeki O.D.D. + çek- yapısında olduğu gibi yük kavramının metaforik çerçevesiyle kuşatılmış olduğu görülür. Metinlerdeki örneklerde; tüşür- fiili yük gibi algılanan olumsuz duygu veya durumun birinin omuzlarına düşürülmesi, yani yüklenmesi, ...DA ara kir- yapısı, birinin yük gibi algılanan olumsuz duygu ve durumun arasına girerek onu yüklenmesi, kötür- fiili olumsuz duygu veya durumun biri tarafından yük gibi "yükseltilip" yüklenilmesi ve taşınması, yüd- fiili birinin olumsuz duygu veya durumu yüklenmesi manalarında kullanılmaktadır.

Harezm Türkçesiyle birlikte, ilk örneği Mukaddimetü'l-Edeb'de görülen O.D.D. + tartyapısındaki birleşik fiiller kullanılmaya başlanmıştır. Orta Türkçe devrinde kaleme alınmış metinlerde çek- ve tart- fiillerinin aynı manalarda ve birbiri yerine kullanıldığı dikkate alınırsa, bu yapının anlam bakımından Türkiye Türkçesindeki O.D.D. + çek- yapısıyla aynı olduğu anlaşılır. Zaten Orta Türkçe devrinde kaleme alınmış metinlerde O.D.D. + tart- yapısı her ne kadar daha sık kullanılmış olsa da O.D.D. + çek- yapısına da rastlanılmaktadır.

\subsection{Köktürkçe, Eski Uygurca ve Karahanlıcada Birleșik Fiillerde Yük Metaforu}

Yenisey Eski Türk Mezar Yazıtlarından Altın Köl I'de ${ }^{11}$ önemli bir şahsın vefatıyla geride kalanlara keder yükü yüklediğinden bahsedilir. Keder yükleme durumu, ilez tüşür-12 birleşik fiiliyle ifade edilir (Tekin 2013: 520). "Keder" manasındaki ilez, tüşür- fiili ile omuzlara yüklenen bir yük şeklinde algılanmaktadır. Daha önce Doğan Aksan da Altın Köl I'de geçen bu kullanımla ilgili olarak yük metaforundan bahsetmiştir (Aksan 2000: 131). Yine, Yenisey Eski Türk Mezar Yazıtlarından Abakan Yazıtı'nda ${ }^{13}$, yazıtı diktirenin babası olduğu anlaşılan Töles kabilesi reisinin vefatıyla ilgili olarak buij tüşür-14 birleşik fiili kullanılır. Kormuşin buij tüşüryapısının Altın Köl I'deki ilez tüşür- yapısı gibi, müteveffanın ölümünün yaşayanlara "üzüntü yüklediğini” gösterdiğini söyler (Kormuşin 2017: 71).

Kuanşi İm Pusar'da, yük metaforuyla ilgili olarak emgeklerinte ara kir-15, adasinta tudasinta ara kir-16, emgekte ara kir-17, muij inta emgekinte ara kir-18 birleşik fiilleri geçer(Ş. Tekin 1960: 9, 19; 17, 24; 18, 24). Şinasi Tekin, bu birleşik fiilleri "1zdırapları arasına girmek" ve "sıkıntıları arasına girmek" şeklinde Türkiye Türkçesine aktarmıştır. Burada ızdırap ve sıkıntının arasına girmekle

11 Yazıt, Güney Hakasya'da Abakan Nehri'nin sağ kıyısında yer alan Altın-Köl Gölü civarında bulunmuştur. Hâlihazırda Minusinsk Şehrindeki N. M. Martyanov Müzesi'nde 27 numarada kayıtlıdır (Kormuşin 2017: 74, 75).

12 İniij izke içiij izke ingen yüki ilez tüşürtüij üz. [=(Ölümünle) küçük ve büyük erkek kardeşlerinin (omuzlarına) dişi deve yükü (kadar) keder yüklediniz.] Talat Tekin, cümleyi İngilizceye "(With your death) you placed a female camel's load of grief on (the shoulders of) your younger and elder brother" şeklinde tercüme eder.

13 Yazıt, Töles kabilesi reisinin anısına dikilmiştir. Orta Hakasya'da, eski Tutatçikov Köyü yakınında, Uybat Nehri'nin Abakan Nehri'ne döküldüğ̈̈ yerde bulunmaktadır. Hâlihazırda 1913'te nakledildiği Minusinksk Müzesi'nde 44 numarayla sergilenmektedir (Kormuşin 2017: 53).

14 Yeti urı og̉liij ız̧̧a bökmedük, ķanıçam, buij 1 tüșürmek ertiij iz [=Sizin yedi oğlunuza doymadan, babacığım, (üzerimize) büyük keder bıraktını] (Kormuşin 2017: 67).

15 Emgeklerinte ara kirip ḳutgarur. [=Izdırapları arasına girip(=1zdıraplarını yüklenip) (onları) kurtarır.]

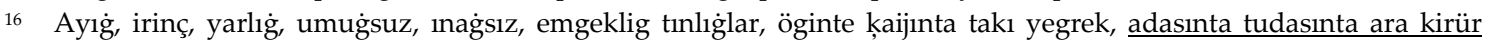
ozġurur. [=Sefil (eş anl.), acınacak hâlde olan, umutsuz (eş anl.) ızdırap çeken canlı varlıkların sıkıntıları (eş anl.) arasına, ana ve babalarından daha iyi girer(=sıkıntılarını yüklenir), kurtarır.]

17 Emgekte ara kirmegey tip... [=Izdıraplarımız arasına girmeyecek(=1zdıraplarımızı yüklenmeyecek) diye...]

${ }^{18}$ Içġınmaz muij ınta emgekinte ara kirür ozgurur. [=Onulmaz ızdırapları (eş anl.) arasına girer(=ızdıraplarını yüklenir), kurtarır.] 
kastedilen, yük gibi algılanan sıkıntı ve ızdırapların arasına girerek, bunları yüklenen kimseye yardımcı olmaktır. Maytrısimit'te yük metaforuyla alakalı olarak ķın, ķızg் $u$ tötür-19 birleşik fiili görülür (Ş. Tekin 1976: 126, 239). kötür- fiilini "(to lift up, to raise); kaldırmak, yükseltmek" şeklinde anlamlandırmak mümkündür (Clauson 1972: 706a). Bu durumda ķın, ķıż่ut kötürbirleşik fiili, "(bir suçun, günahın) cezasını, ceremesini kaldırmak" şeklinde algılanabilir.

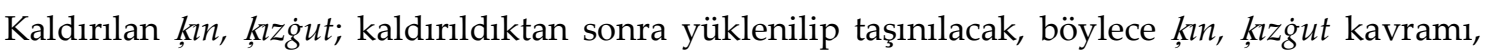
yük gibi algılanmış olacaktır. Türkische Turfantexte V B43'te geçen edgüke tegmeklig yüküg yüd${ }^{20}$ yapısı yük metaforuyla ilgilidir (Bang \& Gabain 1931: 342). Burada yük iyiye ulaşmak için taşınması, yüklenilmesi gereken bir nesne gibi algılanmaktadır. Türkische Turfantexte VI'da (Sekiz Yükmek) emgek kötür-21 birleşik fiili ve emgekli meij ili kentün kötür-22 yapısı görülür (Bang, Gabain \& Rachmati 1934: 52). Emgek kötür- birleşik fiili; ķn, ķzg்utun kötür- fiiliyle, kaldırılıp yüklenilen bir yük gibi algılanması gibi, emgekin de kötür- fiiliyle, kaldırılıp yüklenilen bir yük gibi algılandığını göstermektedir. emgekli meij ili kentün kötür- yapısıyla, emgek, yine kötürfiiliyle kaldırılıp yüklenilen bir nesne gibi algılanmaktadır; ancak yük metaforuyla algılanmaması gereken meij $i$ "sevinç" kavramı, emgek dolayısıyla kötür- fiiliyle birlikte kullanılmıştır.

Kutadgu Bilig'de emgek yüd-23 ${ }^{24}$ ve küçini kötür-25 birleşik fiilleri görülür (Arat 1947: 220, 330, 600; 1959: 153, 238, 433). "Zahmet, meşakkat" anlamında kullanılan ve olumsuz bir durumu ifade eden emgek kavramı yüd- fiiliyle oluşturduğu birleşik fiilde; zahmeti, meşakkati yüklenmek manasında kullanılmıştır. "Zulüm, adaletsizlik" manasındaki ve olumsuz bir durumu ifade eden küç kavramı da, kötür- fiiliyle kaldırılıp yüklenilen bir yük gibi ifade edilmiştir. Dolayısıyla bu iki kullanım, yük metaforuyla ilgilidir. Atebetü'l-Hakayık'ta vebāl yüd-26, vebāl kötür-27 ve emgek kötür-28 birleşik fiilleri yer alır (Arat 2006: 55, 59, 67; 89, 91, 94). Kutadgu Bilig'deki emgek yüd- ve Türkische Turfantexte VI'daki emgek kötür- birleşik fiillerinde

19 Ol yazuķuij uzlarnaij k̦ının ḳızgutın kötürüij ler [=Bu günahlarınızın cezasını, ceremesini çekin!] (Ş. Tekin 1976: 126, 239).

20 Törtünç kirgünç erser edgüke tegmeklig yüküg yüdmekniij tayaḳı titir. [=Dördüncü iman ise, iyiye ulaşmak yük(ü)nü taşımanın dayanağıdır.] W. Bang ve A. v. Gabain bu cümleyi "Was viertens den Glauben anbelangt, so wird er die Stütze beim Aufladen der Last genannt, die zum Guten führt(?)" şeklinde Almancaya tercüme etmiştir.

21 Tamudaḳı emgekin tükel kötürür [=Cehennemdeki ızdırabını tamamen yüklenir.] Bu cümle "Höllen-Qualen alle erdulden" şeklinde Almancaya çevrilmiştir.

22 Emgekli meij ili kentün kötürür. [=Izdırabı da sevinci de kendi yüklenir.] Cümle, Almancaya "Man wird Qual und Freude aus sich selbst ertragen." şeklinde tercüme edilmiştir. Sekiz Yükmek'in J. Oda neşrinde, bu cümle "Suffering and happiness arise of their own accord" şeklinde İngilizceye tercüme edilmiştir (Oda 2015: 235). kötürfiilinin yük metaforuyla ilgili kullanımında "yüklenmek, taşımak" manasına geldiği göz önüne alındığında bunun "They bear (responsibility of) suffering and happines by themselves" şeklinde veya benzer başka bir cümleyle tercüme edilmesi daha uygun görünmektedir.

23 Kişi edgüsi bu öz asġın ķoēup / Kişi asğı ķolsa kör emgek yüdüp [=İnsanların iyisi - kendi menfaatini bırakıp, zahmet yüklenerek, başkalarının faydasını isteyen kimsedir.]

24 Meniij bu özüm k̦açtı dünya ḳoēup / Bu yirde turur men kör emgek yüdüp [=Ben ise, bu dünyayı bırakıp kaçtım; zahmetlere katlanarak, burada yaşıyorum.]

25 Bu küçkey kişi kendü beglik yimez / Bu küçkey küçini budun kötrümez [=Zâlim adam uzun müddet beyliğe sahip olamaz; zâlimin zulmüne halk uzun müddet dayanamaz.]

26 Bu dünya neij indin yigü keēgülük / Al artuḳ tileme vebal yüēgülük [=Bu dünya malından yiyecek ve giyecek (kadarını) / Al; fazlasını isteme, (fazlası) yüklenilecek vebâldir.]

27 Baĥl tirdi zer sim garamdın öküş / Vebal kötrü bardı özele söküş [=Hasis, haram ile, çok altın ve gümüş topladı, vebal yüklenerek ve üstelik bir de söğüş alarak, gitti.]

28 Küç emgek tegürme kişike ķalı / Saij a tegse emgek kişidin kötür [=Başkasına zorluk ve zahmet çektirme, eğer sana başkası eziyet ederse, tahammül et.] 
görüldüğü gibi, yüd- ve kötür- fiilleri olumsuz duygu ve durumları ifade eden vebāl ve emgek kavramlarının yük gibi algılanmasını sağlamaktadır. Atebetü'l-Hakayık'taki kullanımlarda dikkat çekici olan Arapça vebāl kelimesinin, Türkçe emgekin yerini almasıdır.

2.2. Harezmce, Doğu Türkçesi ve Eski Anadolu Türkçesinde çek- ve tart- ile Kurulan Birleşik Fiillerde Yük Metaforu

Köktürkçe, Eski Uygurca ve Karahanlıcada görülen tüşür-, ...DA ara kir-, kötür-, yüd- filleri; Harezmce-Kıpçakçadan itibaren, yük kavramıla çerçevelenmiş birleşik fiilleri teşkil etmede yerini çek- ve tart- fillerine bırakır. Yük metaforuna malik birleşik fiiller; Harezmce, Doğu Türkçesi ve Eski Anadolu Türkçesinde O.D.D. + çek- ve O.D.D. + tart- yapılarıyla ifade edilecektir. Buna karşılık; Köktürkçe, Eski Uygurca ve Karahanlıcada çek- ve tart- fiillerinin yük metaforuyla ilgili bir kullanımına rastlanılmaz. Bu devirlere ait metinler tarandığında ${ }^{29}$, tartfiilinin 17 farklı anlamda, çek- fiilinin iki farklı anlamda kullanıldığ görülür. Bu anlamlar arasında yük metaforuyla ilgili hiçbir kullanıma rastlanılmamaktadır.

Taranan metinlerde 87 kez geçtiği tespit edilen tart- fiilinin 17 farklı anlamı şöyledir ${ }^{30}: 1$. Asılmak, tutup asılmak; söküp çıkarmak; koparmak ${ }^{31}$, 2. (Üzerinde bulunan bıçak, k1lıç vb. silahları) kullanmak üzere çekip çıkarmak; (yayı) germek ${ }^{32}$, 3. (Bir şeyi veya birini, kendine doğru veya bulunduğu yerden başka bir yere) getirmek, götürmek; (bir şeyi bir yere doğru) uzatmak $^{33}$, 4. Uzaklaştırmak, ayırmak; kurtarmak ${ }^{34}$, 5. Çekişmek, tartışmak, anlaşamamak ${ }^{35}, 6$. (Örü ile birlikte yahut tek başına; bir şeyi, birini hem mecazi hem doğrudan anlamıyla) yukarıya çıkarmak, yükseltmek ${ }^{36}$, 7. Alıkoymak, el koymak, zorla alıp tutmak ${ }^{37}$, 8. Cezbetmek,

29 Yukarıda bahsedilen maksada binaen; Orhun Yazıtları (T. Tekin 1994, T. Tekin 2008, Berta 2010), Uygur Runik Yazıtları (Berta 2010), Yenisey Eski Türk Mezar Yazıtları (Kormuşin 2017); Huastuanift (Özbay 2014), Altun Yaruk (Çağatay 1945, Ölmez 1991, Kaya 1994, Uçar 2009, Ayazlı 2012, Çetin 2012, Gulcalı 2015), Kuanşi İm Pusar (Ş. Tekin 1960), Maytrısimit (Ş. Tekin 1976), Sekiz Yükmek (Oda 2015), Edgü Ögli Tigin Anyıg Ögli Tigin (Tulum \& Azılı 2015), Daśakarmapathāvadānamālā (Elmalı 2016), Eski Uygurca Din Dışı Metinler (Ayazlı 2016); Kutadgu Bilig (Arat 1947, 1959, 1979), Divanu Lügati't-Türk (Dankoff \& Kelly 1982, 1984, 1985), Atebetü'l-Hakayık (Arat 2006), Karahanlıca Satıraltı Kuran Tercümesi (Eckmann 1976) taranmıştır.

30 Bir kullanımın anlamı, metinde eksik kısımlar olduğu için tespit edilememiştir: DKPAM 1991 tartıp [kèç]medin [=1]

31 AY-Ç 19, 14 yıra yırta tartarlar yırarlar, EÖT-AÖT 206 ışığag tartgay men, DKPAM 1214 azıgların öij i öij i tartıp, DKPAM 1324 azıgımın tartar erken, DKPAM 1777 agızıntın tilin tartıp, DKPAM 3132 yürekin tarta alıp, DKPAM 4705 yürekin tarta, DKPAM 2281 saçların tartıp, DKPAM 3532 saçın tarta tutup, DKPAM 3883 (başındaki saçlardan?) birin tartmış teg, DLT I 122 saķal tutup tartışur, DLT II 369 ol maij a uruḳ tartışdı, DLT II 628 ol yip tarttı [=13]

32 DKPAM 324 yitti kılıçın tartıp, DKPAM 1424 yitti biçekin tartıp, DKPAM 1427 yitti biçek tartmışın, DKPAM 1263 agulug okın saplap toşguru tartıp, DKPAM 3560 ya tartıp, Maytr. 110, 5 1rg̉ag tartar, Maytr. 75, 16 üç adrı süij ün (...) tartarlar, Maytr. 78, 43 üç adrı süij ün tartarlar, KB 4131 biçek tartma, KB 4599 bıçaķ tartma, DLT II 369 ol menig birle ya tartışdı $[=11]$

33 AY-K 602, 7 balık tartgu simekin(?) (bkz. Clauson 1972: 829a), AY-G 616, 7 örü tartıp, AY-Ç 639, 11 tartıp yigeli umadı, DKPAM 350 Aviş tamuka tartıp, Maytr. 57, 31 tartıp Avıç tamuķa kigürdi, Maytr. 66, 15 tilimizni ag̉zımıztın taşgaru tartıp, EUDDMKS ${ }_{226}$ tartıp yançıg turulduru saçmışta, EUDDMKS ${ }_{228}$ kızıl öküzlerig tartıp, KB 4131 aşıg tartmagìl, DLT II 386 ol evke tarig tartındı, RIKT 276 tarttı elgini [=11]

34 AY-K 103, 22 tartayın üntüreyin alku tınlıg oglanların, AY-K 122, 21 üç yavlak yolka baru tartdaçı üçün, AY-U 0570 taşgaru tartdım tınlıglarıg, AY-A 430, 10 sansarlıg tegzinçtin taşkaru tartıp AY-G 618,1 emgektin tartmaklıg buyanıij 1Z, AY-G 613,22 tugmak ölmeklig tegzinçdin taşgaru tartıp, DKPAM 1861 togumlug amranmakın kèterü tartıp, DKPAM 2175 tartıtıp bu yėrtinçüde, DKPAM 3158 tarta oglıntın adırıp, KB 5442 elig tarttı aştın [=10]

35 EUDDMKS 487 ilmezün, tartmazun, EUDDMKS 487 ilgeli tartgalı sakınsar, RIKT 276 tartıştij $1 z$ erse, RIKT 276 tartışmağıl anlardın, RIKT 276 tartışmazlar Taij rınij āyātları içinde, RIKT ${ }_{276}$ tartışur sizler anıij içinde, RIKT 276 tartışur uruşur özindin [=7]

36 DKPAM 4192 üç yavlak yolta tüşmiş tınlıglarıg örü tartıp, KB 86 tarttı haķan tuġı, KB 3091 örü tartġıl özni, KB 5426 örü tart özüij , DLT II 611 ķaij daş ķama urur, ögdeş örü tartar [=5]

37 DKPAM 1423 ogulın tarta alıp, Maytr. 62, 34 tartdımız istimiz, Maytr. 70, 61 tartdımız, yaşuru baturu og ourladımız, Maytr. 82,6 ödsüz kolusuz tartıp, DLT II 628 ol tartın tarttı [=5] 
etkisi altına almak; sevketmek, sürüklemek ${ }^{38}$, 9. Sürüklemek, çekiştirmek, itip kakmak ${ }^{39}, 10$. A ğırlığını ölçmek ${ }^{40}$, 11. (Erk ve/veya türk ile birlikte) güç kazanmak; hükmetmek ${ }^{41}$, 12. (Bir şeyi bulunduğu diğer şeylerin veya bir şeyin arasından) almak, alıp çıkarmak ${ }^{42}$, 13. Ortaya çıkarmak ${ }^{43}$, 14. Örtmek, kapatmak ${ }^{44}, 15$. Şefkat göstermek ${ }^{45}$, 16. Bir şeyin parçalarının birbirini çekmesi ${ }^{46}, 17$. Bir şeyin çekiştirilip koparılmasından dolayı acı hissetmek ${ }^{47}$. Taranan metinlerde 7 kez geçtiği tespit edilen çek- fiilinin iki farklı anlamı şöyledir: 1. Yazı yazmak ${ }^{48}$, 2. Kan almak, hacamat etmek ${ }^{49}$. Kaydedilen anlamların hiçbirinde çek- ve tart- fiillerinin yük metaforuyla ilgili bir anlamına rastlanılmamaktadır. Ayrıca, DTS ve EDPT'de ve çek- ve tart- maddelerinde; Köktürkçe, Eski Uygurca ve Karahanlıca dönemi için yük metaforuyla ilgili bir kullanım kaydedilmemiştir (Nadalyaev vd. 1969: 143a, 538b) (Clauson 1972: 415a, 534b).

Köktürkçe, Eski Uygurca ve Karahanlıca metinlerde çek- ve tart- fiillerinin, yük metaforuyla ilgili bir kullanımına rastlanılmamakla birlikte, Harezm-Kıpçakçayla beraber bu fiillerin ilgili metaforla alakalı olarak kullanılmaya başlandığı görülür. Ez-Zemahşerî el-Harezmî (ö. 1144) tarafından 1128-1144 yılları arasında kaleme alındığı düşünülen Mukaddimetü'1-Edeb'de emgek tart-50, gurbet tart-51, işniij yükin tart-52 birleşik fiilleri bulunmaktadır (Yüce 2014: 57, 65, 68). 1291, 1292 veya 1293 yıllarından birinde kaleme alınmış olması muhtemel (Argunşah \& Güner 2015: 24) Codex Cumanicus'ta emgek tart-53 birleşik fiili geçer (Argunşah \& Güner 2015: 308). Nâsırüddin b. Burhanüddin Rabguzi (ö. 1310'dan sonra) tarafından 1310 yılında tamamlanan Kısâsü'1-Enbiyâ'da mihnet tart-54, emgek tart-55 birleşik fiilleri görülmektedir (Ata 1997: 108, 326). İslâm (ö. 1313'ten sonra) adlı bir âlimin (son bölümünü Ürgençli Şeyh Şeref Hoca'nın) 1313'te kaleme aldığı Muînü'l-Mürîd'de şeríat yükin tart-56 birleşik fiili geçmektedir (Toparlı \& Argunşah 2008: 139). Kutb'un (ö. 1342'den sonra) tahminen 1341/2 yılları arasında kaleme aldığ

38 AY-Ö ${ }_{131,10}$ ol yaruklug yalınçınga tartılıp, DKPAM 3890 köij ülümin [...] kunup tartıp, KB 5739 isiz yolķa tartgay, KB 6369 otḳa tartar, KB 6372 küvezlikke tartar, [=5]

39 AY-Ç 10, 9 öij dürti tarta, DKPAM 936 butarlayu tartıp, DKPAM 2337 tartıp èltip barırlar DKPAM 4024 ite tarta kay kay sayu èltdiler [ $[=4]$

40 EUDDMKS 491 tükel tartıp altım, DLT II 369 ol maij a altun tartışdı, DLT II 381 yarmaķ tartıldı, DLT II 628 ol yarmaķ, tartt, $[=4]$

41 AY-A 411, 3 kentü èl uluşlarınta erk tartıp, Maytr. 2, 41 erk tarta umaz, Maytr. 47, 24 tört uluşlar öze ür ödün erk türk $\operatorname{tart}(\operatorname{tim})[=3]$

42 Maytr. 73, 27 tartıp birür erdimiz, DLT 628 ol etükin tartt1, DLT II 628 suv körmeginçe etük tartma [=3]

43 AY-U 0498 öij i tüşüg tartarlar [=1]

44 AY-EÇ 478, 6 törtdin yiij ak bıntavır taršı [=1]

45 DLT II 386 er ogiliij a tartınd1 [=1]

${ }^{46}$ DLT II 36 tartışdı neij [=1]

47 DLT II 557 yazıda böri ulısa evde it bağrı tartışur [=1]

48 DLT I 275 ol bitig çekti, DLT II 322 ol maij a çekig çekişti, DLT II 335 bitig çekildi, DLT II 342 er bitigke çekig çekindi, DLT II 357 aij ar çekig çektürdi [=5]

49 DLT I 275 ol atın çekti, DLT II 357 ol atın çektürdi [=2]

50 125-6: Emgekin tartdı aniij [=Onun zahmetini çekti.] ve 126-3: Emgekiij tartdı anij [=Onun zahmetini çekti.]

51 128-4: Gurbet tarttı, ıraķ bardı èlindin [=Gurbet çekti, memleketinden uzağa gitti.] ve 166-6: Gurbet tarttı, garíb boldı, èlindin yıradı [=Gurbet çekti, yabancı oldu, memleketinden gitti.]

52 179-5: İșniij yükin tartdı, iş özine bag̉ladı, tekellüf birle k̦ıldı. [=İşin yükünü(=zahmetini) çekti, işi kendi üstlendi, zorla yapt.]

53 Biz yuvunalı emgek tarttiij [=Bizim arınmamız için zahmet çektin.].

54 Yūsuf munça ķurbet birle miǵnet nelük tarttı... [=Yusuf, bunca yakınlıkla niçin zahmet çekti...]

55 Andag èrse bu ne horluḳ turur biz körer-miz, bu ne èmgek turur biz tartar-miz... [=Öyleyse gördüğümüz bu ne horluktur, çektiğimiz bu ne zahmettir...]

56 Şerí‘at yükin tart yöri rāst köni/ Eşitgey ķulaḳın šaríḳat üni [=Şeriat yükünü yüklen, doğru yürü. Kulağın tarikat sesini işitsin.] 
Hüsrev ü Şîrîn'de renc tart-57 ve emgek tart-58 birleşik fiilleri görülür (Zajaczkowski 1961: 172). Mahmud b. Ali'nin (ö. 1360) 1358'den önce yazdığ1 tahmin edilen Nehcü'l-Ferâdis'te zagmet tart-59, zagmet meşaķķat tart-60 ve emgek tart-61 birleşik fiilleri görülür (Tezcan \& Zülfikar 2014: 99, 284). Altın Ordu, Kırım ve Kazan Sahasına Ait Yarlık ve Bitikler'den 1478 tarihli Eminek Mirza Bitiği'nde zaǵmet çek-62 birleşik fiili bulunmaktadır (Özyetgin 1996: 124).

Harezm-Kıpçak Türkçesinde çek- ve tart- fiilleri, yük metaforuyla ilgili olarak kullanılmaya başlanmış, Doğu Türkçesinde bu durum sürdürülmüştür. Yûsuf Emîrî Divanı'nda (ö. 1433) bídād çèk-63, zagmet çèk-64, derd ü belā çèk- ve cefā çèk-65 birleşik fiilleri görülür (Köktekin 2007: 104, 142, 302). Sekkâkî Divanı'nda (ö. 1449'dan önce) mecālını tart-66 "zorbalığına katlanmak" birleşik fiili yer alır (Eraslan 1999: 252). Lutfî Divanı'nda (ö. 1492) cevr çèk-67, cevr-i nādān tart-68, renc-i hicrān tart-69, belā çèk-70, elem tart-71, cefā tart-72, intižār çèk-73, firķat çèk-74, firāk ķ tart-75, derd

57 Umınçım bar eger tart[t]iij sa köp renc / İliij e kirgey ol imdi revān genc [=Eğer çok zahmet çektiysen, şimdi o yürüyen hazinenin eline gireceğine inancım var.] (Hacieminoğlu 1968: 248)

${ }^{58}$ Ķayu köij lek minim 'işkıımda yırttıij / Ķayu emgek minim '1şkıımda tarttıij [=Hangi gömleği benim aşkımda yırttın? Hangi zahmeti benim aşkımda çektin?] (Hacieminoğlu 1968: 375).

59 Men, bu keç̧e taḳı Ģaķ riżāsı üçün bu etmekni ol esírke bẻrür-men taķı açlık zaǵmetini bu kèçe taḳı tartar-men. [=Ben bu gece de Allah rızası için bu ekmeği o esire vereceğim ve açlık zahmetini bu gece de çekeceğim.]

60 Nẻ ėmgek kim bizler bu isig havāda körer-miz taḳı bu açlıḳlar zaǵmetini taḳı meșakkkatini tartar-miz [=Ne zahmet ki bizler bu sıcak havada görüyoruz, bu açlık zahmetini ve meşakkatini çekiyoruz...]

61 Yā Resūlallāhi, bizler bu isigde munça ėmgek tartıp og̉ul ķızdın aērılıp... [=Ya Resulullah, bizler bu sıcakta bunca zahmet çekip evlattan ayrilıp...]

62 Nūr Devlet ile G̦aydar sebebidin ötürü epeyi zağmetler çeker-miz [=Nur Devlet ve Haydar'dan ötürü, epeyi eziyet, zahmet çekeriz.]

63 Çèkip cān u köij ül bí-dādlar hicrān cefāsıdın/ Emír aldıg̉a barıp dād iterg̉a zārlardurlar [=Can u gönül, ayrılık cefasından eziyet çekip (Yusuf) Emîrî́nin huzuruna varıp adalet için ağlamaktadır.]

64 Meni cānım alurg̉a èy ecel köp çèkmegil zag̣met/Ki bir söz birle la‘li maij a ölmekni muǵāl itmiş [=Ey ecel, benim canımı almak için çok zahmet çekme; çünkü (sevgilinin) dudağı bana ölmeyi bir sözle imkânsız kılmıştır.]

65 Köij ül 'āşıķlığın terkin itip derd ü belā çèkme/ Vefāsız bí-mürüvvet dilrübālardın cefāa çèkme [=(Ey) gönül, âşıklığını terk edip derd ü bela çekme; vefasız, insafsız güzellerden cefa çekme.]

66 Bizni raḳíbler öltüredür, yoḳ saij a haber / Ey vāy, niçe tartalı itler mecālını [=Bizi rakipler öldürmektedir, seninse haberin yoktur; eyvah itlerin zorbalığını nasıl (ne kadar daha) çekelim?] Aynı beyte Lutfî divanında da rastlanmaktadır. Lutfî́de beyitteki itler mecālını kelime grubu yerine itler maǵälını kelime grubu vardır (Karaağaç 1997: 257). Karaağaç maǵăl kelimesini Arapça kökenli bir kelime olarak değerlendirip "düşmanlık" manasını vermiştir (Karaağaç 1997: 556).

67 Bir k̦atıḳ cānlı̣ cihānda körmedim köij lüm bigin/ Kim çèker cevr ü burunḳı 'ahd u peymānındadur [=Cihanda gönlüm gibi cefa çekip sert canı (olan bir şey) görmedim; (bu, onun) önceki ahdinden, yeminindendir.]

68 Yoḳ turur yalġuz bu Lušfí cāniġa cevr-i raķíb/ Ķayda bir dānā durur ol cevr-i nādān tartadur [=Yalnız, bu Lutfî́nin canına rakibin cevri yoktur; o öyle bir âlimdir, cahilin cevrini çekmektedir.]

69 Bardı birmey şerbet-i vaŝlın bu hasta Lušfíga/ 'Ömr bardı vü henūz ol renc-i hicrān tartadur [=(Sevgili) bu hasta Lutfí’ye kavuşma ilacını vermeden gitti; ömür gitti, o (Lutfî) hâlâ ayrılık sızısı çekmektedir.]

70 Ol elif boyluḳ sanemniij g galḳa ğalḳa zülfidin/ Niçe kim çèktim belālar dimedim yüzinde lām [=O elif boylu sanemin halka halka zülfünden nice belalar çektim; (ama) yüzünde eğrilik (var) demedim.]

71 Körgeli ķadd u zülf ü ag̉ziij nı/ Tartadur biz besí elem sẻndin [=(Elif gibi) boyunu, (lâm gibi) zülfünü ve (mim gibi) ağzını gördüğümüzden beri, biz senden çok elem çekiyoruz.]

72 Tartaram yüz miij cefā köij lüm èlindin kāşkí/ Bẻrgey èrdi G̣aḳ köij ül bẻrginçe seng-i hâareí [=Gönlüm elinden yüz bin cefa çekiyorum; keşke Allah gönül (cefa) verince (bağrıma basmak için) bir mermer taş verseydi.]

73 Lušfíga kim işikte çèker yıllar intižār/ Bir kün öterde köz uçıdın merǵabā ķanı [=Yıllarca eşiğinde bekleyen Lutfí'ye, bir gün geçerken göz ucuyla merhaba hani?]

74 Firkatiij nı çèkkeli cān k̦aydadur/ Ŝabr èterge sẻnsiz imkān ķaydadur [=Firkatini çekecek can nerededir, sensiz sabretmeye imkan nerededir?]

75 Tarta almas min firāḳıiij nèteyin/ Ķılça tenge bār-1 '1şł̧ıij šaķ ėrür [=Ayrılığının (yükünü) kaldıramıyorum, ne yapabilirim? Kıl kadar tene aşkının yükü(nü kaldırmak) zordur.] 
tart-76 birleşik fiillerine rastlanır (Karaağaç 1997: 53, 72, 74, 127, 168, 191, 240, 280, 292, 296). Ali Şîr Nevâyî'nin (ö. 1501) 1483 tarihinde kaleme aldığ1 Hayretü'l-Ebrâr'ında ġûŝsa çèk-77, miǵnet çèk- ve minnet tart-78, dest-renc çèk-79, renc çèk-80, ġam çèk-81, sitem çèk-82, humār çèk-83, ta áb tart-84, 'aźäb çèk-85, žulm çèk-86, renc tart-87 birleşik fiilleri görülür (Sabir 2016: 230, 248, 272, 323, 337, 348, 392, 424, 442, 446). Nevâyî'nin Târîh-i Mülûk-1 'Acem'inde riyāzetler ve mücāhedeler tartmak ${ }^{88}$ (Abik 1993: 213), Münşe'ât'ında zagmet tart-89, fenā gummārını tart-90, riyāziyyetini tart-91 birleşik fiilleri geçer (Abik 1993: 341, 374, 395). Hüseyin Baykara Divanı'nda (ö. 1506)'aźāb tart-92, hacālet tart-93, ķahr tart-94, cefā tart-95 96, ġam tart-97, derd ü ġam u āzār tart-98 birleşik fiilleri görülür (Yıldırım 2010: 61, 75, 88, 94, 123, 133, 205):

76 Tapķa mẻn dip vaŝlıdın bir kün devā/ Tartaram dāyim firāḳıij derdini [=Bir gün kavuşmanın devasını bulayım deyip daima ayrılı̆̆ının derdini çekiyorum.]

77 Ǵuŝŝa cihān içre çėkip cān üçün/ Cānnı fidā ḳılgalı cānān üçün [=Can için cihanda zahmet çekip canan için canı feda etmeli.]

78 Sèn dag̀ı çèkkil bu tiken miğnetin/ Tartmağıl Ģātem-i Šay minnetin [=Sen de bu dikenin mihnetini çek, Hâtem-i Tay'ın (cömertliğinin) minnetini çekme.]

79 Bir direm almaḳ çèkiben dest-renc/ Yahşsıraḳ andın ki birev birse genc [=Bir dirhem almak (için el emeğinle) zahmet çekmek, birinin hazine vermesinden yeğdir.]

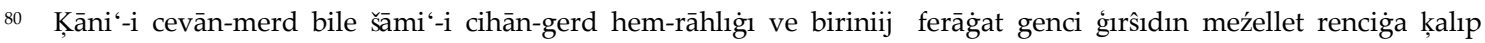
biriniij k k̦anā'at renci çèkerdin ferāgat gencige yètkeni [=Cömert kanaatkâr ile dünyaperest tamahkârın yoldaşlığı ve birinin feragat hazinesi hırsından mezellet rencine kalıp birinin kanaat renci çekmekten feragat hazinesine ulaşmasi.]

81 Beyle gaam u miǵnet-i devrān çèkip/ On u on bėş yıl yügürüp cān çèkip [=Böyle gam ve devranın mihnetini çekip on, on beş yıl can çekişerek dolaşıp...]

82 Nėççe sitem ķılġuçı ābād olup/ Barça sitem çėkküçi ber-bād olup [=Nice zalim âbat olup bütün mazlumlar berbat olup...]

83 Her kişi gül ıslasa hār ol çėker/ Bāde birev çikse ḥ̂ūār ol çèker [=Gülü sulayan kimse dikene katlanır, biri şarap içince humarı o çeker.]

84 Ġazvda kim ölmese tartıp ta‘ab/ Āb-1 gaayāt içre èrür teşne-leb [=Savaşta eziyet çekip ölmese (de), âb-1 hayâtta susuzdur.]

85 Ėl dag̣ı ol ķahrdın alġay ǵisāb/ Ölgey alar daġ çèkip köp ‘aźāb [=El âlem dahi o kahırdan hesap alsın, onlar dahi çok azap çekip ölsün.]

86 Cān ki çèker žulm demí şād itey/ Ten üyin ol su bile ābād itey [=Zulüm gören canı bir an şad edeyim, ten evini o suyla âbat edeyim.]

87 Yā nẻ ŝ̀fat tarttı Ēaǵgāa renc/ Tẻij ri naŝíb ètti Ferídūn'g̉a genc [=Yâ ne sıfat (buldu) Dahhâk renc çekip, Tanrı Feridun'a hazine nasip etti.]

88 Ve ol gebr dínide riyāżetler ve mücāhedeler tartıp èrdi. [=Ve o, Mecusi dininde riyazetler ve mücahedeler çekmişti.]

89 Bu müddetde zaǵmet tartıp yasagan muraḳķa'nı ve her miḳdār tekellüf ḳılıp tüketken kitāblarnı kim bulardın özge híç nimege hāăšr-bestelıķ yoķ irdi alıp kilip irdim. [=Bu süre zarfında, zahmet çekilip derlenen mecmuayı, ne kadar uğraşılıp bitirilmiş kitapları ki bunlardan başka hiçbir şeye gönül bağı yoktu, alıp gelmiştim.]

90 Her kimge kim beḳā cāmıdın neş'e yètişdi fenā humārını tartardın güzíri yoḳdur. [=Beka kadehinden yudumlayanın fanilik sarhoşluğunun baş ağrısını çekmekten kaçınması olmaz.] Bu örnek El-lugâtu'n-Nevâiyye ve'l-istişhâdâtu'lcagatâ'iyye'de de geçmektedir (Kaçalin 2011: 387).

91 Bu faḳírniij munça vaḳtlı̀ sa'y u ėmgekini ve özüij yıllar tartkan riyāziyyetiij ni... [=Bu fakirin bunca zamanlık çalışma ve emeğini ve sizin yıllardır çektiğiniz riyazetinizi...] Bu örnek El-lugâtu'n-Nevâiyye ve'l-istişhâdâtu'lcagatâ'iyye'de de geçer (Kaçalin 2011: 387).

92 Vaŝlı iķbālide köp āzürde-mèn ag̉yārdın/ Veh nẻ šāii‘dür ki tartar-mèn behişt içre a aźāb [=(Sevgiliye) kavuşmanın ikbâlinde (dahi) rakiplerden (dolayı) kırgınım. Vah ne talihtir ki cennette azap çekiyorum.]

93 Ay yüzüij dik körmeyin bir mihr-i devrānıda çerh/ Bil ki köp tartıp ĥacālet mihr-i raĥşānıda çerĥ [=Çarh; ay yüzün gibi felekte bir güneş görmeden, bil ki (kendi) parlak güneşinden çok utanmıştır.]

${ }^{94}$ Ķahr cāmın dem be-dem tartar-mèn ol bed-hūyniij / Gūyiyā Tẻij ri mẻni halķ èylemiş tartarğa kahr [=O huysuzun kahır kadehini zaman zaman içerim. Sanki Allah beni kahır çekmek için yarattı.] Bu örnek El-lugâtu'n-Nevâiyye ve'listişhâdâtu'l-cagatâ'iyye' de de geçmektedir (Kaçalin 2011: 385). 
Harezm-Kıpçak Türkçesinde ve Doğu Türkçesinde olduğu gibi Eski Anadolu Türkçesinde, çek- ve tart- fiilleri yük metaforuyla ilgili olarak kullanılır. Hoca Mesut'un 14. asırda kaleme aldığı Süheyl ü Nevbahar tercümesinde belā dart-99, Âşık Paşa'nın 14. asırda telif ettiği Garibnâme'de zagmet dart-100, Yazıcı Salâhüddin Efendi'nin 15. asrın başlarında kaleme aldığ1 Melhame-i Şemsiyye Tercümesi'nde renc ile ăh tart-101, Larendeli (Karamanlı) Hamdi'nin 16. asrın ortalarında yazıp o yıllarda Karaman valisi olan şehzade Selim'e sunduğu Leylâ vü Mecnûn'da derd ü mignnet tart-102 birleşik fiillerine rastlanılmaktadır (T.D.K. 1965: 1016, 1017).

\subsection{Farsçada O.D.D + keşíden Yapısı}

Türkçede çek- ve tart- fiilleriyle kurulan birleşik fiillerde yük metaforunun, Harezmce devrinden itibaren görülmeye başlamasında Farsçanın etkisi olduğu düşünülebilir. Deniz Abik, Ali Şir Nevâyî'nin Târîh-i Enbiyâ ve Hükemâ, Târîh-i Mülûk-1 'Acem ve Münşe'ât adlı üç eserindeki birleşik fiilleri Farsçayla mukayeseli olarak incelediği araştırmasında, Türkçe birleşik fiiller ile Farsça mukabilleri arasında nasıl bir yakınlık olduğunu ortaya koyar. Mesela Türkçedeki äferin oku-, dest bir-, gam yi-, intiķām tart-, ķadem ur-birleşik fiillerine Farsçada äferin $h^{w} \bar{a} n d e n$, dest dāden, gam horden, intiķām keşíden, ķadem zeden şeklinde rastlanılmaktadır. Dikkat edilirse, oku-, bir- , yi-, tart-, ur- fiilleri; Farsça yapılarda, bunların birebir tercüme şekli olan h́wānden "okumak", dāden "vermek", horden "yemek", keşílen "çekmek", zeden "vurmak" kelimeleriyle karşılanmıştır. Abik, birleşik fiillerde görülen bu müşterekliğin sebebini açılamaz. Farsça'nın mı Türkçe'yi yoksa Türkçe'nin mi Farsça'yı etkilediğinin tespiti için her birleşik fiilin en eski kaynaklardan itibaren izlenmesi gerektiğini vurgular (Abik 2004: 221).

Çek- ile tart- fiilleriyle kurulan ve yük metaforunu içeren birleşik fiillerde, Abik'in incelemesindeki gibi Farsçayla bir ortaklaşma görülmektedir. Steingass sözlüğünde kashīdan "çekmek" maddesinde, kelimenin "to bear", "to carry", yani "taşımak", yüklenmek" anlamları kaydedilmekte, zagmat kashìdan "to take pains, to give one's self the trouble", yani "zahmet çekmek"; sharm kashīdan az "to be ashamed of", yani "utanmak, utanç çekmek", gurusnagī kashīdan "to suffer hunger", yani "açlık çekmek", nāzi kase kashīdan "to bear up with one's arrogance", yani "nazını çekmek" örnekleri verilmektedir (Steingass 1977: 1035a, 1035b). Ziya Şükûn'un Ferheng-i Ziyâsında ise keşíden'in ismi mefulü olan keşíde "çekmiş, çekilmiş" maddesinde, "Çekmek kelimesinin lisanımızda kullanılan manaları kısmen Farsçada kullanılır: Mesela zahmet çekmek gibi ki sanki zahmeti omuza alıp götürmektedir" denir (Şükun 1984: 1548a). Ziya Şükûn da zahmet çekmek birleşik fiilindeki yük metaforunu sezmiştir. Hasan

95 Anlaij èy ehl-i vefā ger ölseij iz tartıp cefā/ Bí-vefālardın vefā resmi temannā ḳılmaij $1 z$ [=Ey vefa ehli, cefa çekip ölseniz de vefasızlardan vefanın izini (dahi) dilememeniz (gerektiğini) anlayın.]

96 Bilmegenler 'ş̧̧̧ bí-dādını Mecnūn gaālig̉a/ Pür-cefā min tartḳan türlüg cefālardın biliij [=Mecnun'un haline aşk zulmünün (ne ettiğini) bilmeyenler; (ben de) pür-cefayım, (Mecnun'un hâlini) çektiğim türlü cefalardan anlayın.]

97 Çün gam u feryād u efḡānı èrür gül şevḳıdın/ Her nihāl üzre eger bülbül nevā tartar nè gàam [=Her fidanda eğer bülbül şakıyıp üzüntü çekmiyorsa; üzüntüsü, feryadı ve figanı güle (duyduğu) şevkten (olduğu) içindir.]

98 Nęçe kim tartar köij ül derd ü gam u āzārını/ Mihrim artar néçe kim körsem meh-i ruhsārını [=Gönlüm derdini, gamını, azarını çektiği (ve) ay (gibi) yüzünü gördüğüm kadar sevgim artar.]

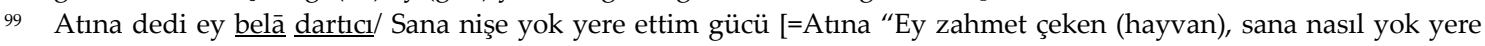
zorluk çıkardım?]

100 Malı çok̦, dartar bu dünyā zağmetin/ Hem gümāndır ki bula Ģaḳ rağmetin [=Malı çok, bu dünyanın zahmetini çeker, Allah'ın rahmetini bulacağı da şüphelidir.]

101 Çünkü ḳısmet buladır gükm-i İlāh/ Pes niçin tarta kişi renc ile āh [=Allah'ın hükmü kısmet olunca, şüphesiz insan niçin dert mihnet çeksin?]

102 Kimi gülşende sürer '1yş ü 'işret/ Kimi külhhanda tartar derd ü miǵnet [=Kimi gül bahçesinde ayş u işret sürer, kimi külhanda dert ü mihnet çeker.] 
Amîd'in sözlüğü Ferheng-i Amîd'de de keşíden maddesinde, derd keşíden ve renc keşíden örnekleri verilir (Amîd 1374: 1974a).

Farsçanın en geniş sözlüğü sayılan ve tanıklarla desteklenen ${ }^{103}$ Ali Ekber Dihhudâ'nın Lugatnâmesi'nde O.D.D. + keşíden yapısı için endûh keşîden, intizâr keşîden, belâ keşîden, telhî keşîden, tengî keşîden, cefâ keşîden, ceur keşîden, hasret keşîden, hacâlet keşîden, derd keşîden, renc keşîden, rencûrî keşîden, zahmet keşîden, sitem keşîden, azâb keşîden, firâk keşîden gibi pek çok örnek mevcuttur (Dihhudâ 1334: 16210, 16211). Lugatnâme'de örnekler için tanıklar da yer alır. Mesela renc ü belâ keşîden için Firdevsî (ö. 1020)'den şu beyit tanık gösterilmiştir:

$$
\text { ازيه مايه كثيديم رنج و بلا اهر من كيش دوش ازدهـا }
$$

Tengî keşîden için Nâsır-1 Hüsrev'in (ö. 1073'ten sonra) bir beyti tanıklar arasında yer alır:

$$
\text { كدار اكن مده كردن خسان را همجو آز ادان }
$$

Belâ keşîden için verilen tanıklar arasından biri Mes'ûd-ı Sa'd'a (ö. 1121) aittir:

$$
\text { ورنو سنگى بلاى سختى كش ایى سنى بشكن و بكذار }
$$

Endûh keşîden için Abdülvâsi-i Cebelî́den (ö. 1160) aşağıdaki beyit tanık gösterilmiştir:

$$
\text { بار آن باشد كه انده يار كثد }
$$

\section{Sonuç}

1. Anlamca kalıplaşmış veya deyimleşmiş birleşik fiiller, Lakof ve Johnson'ın metafor kuramına göre yorumlanabilir. Türkiye Türkçesindeki derdini aç-, duygularını aç-, ruhunu aç-, yüreğini aç- birleşik fiillerinin ardında DUYGU VE DÜŞÜNCELER KAPALI BİR NESNEDİ; işi gevşek tut-, sıkı çalış- birleşik fiillerinin ardında CIDDIYYET SIKI, CIDDIYYTSIZZLIK GEVŞEKTIR; aklından çıkar-, hatırından çıar- birleşik fiillerinin ardında AKIL MEKANDIR metaforlarının yattığı görülmektedir.

2. Türkiye Türkçesinde görülen acemilik çek-, acı çek-, azap çek-, cefa çek-, çile çek-, derdini çek-, eziyet çek-, gü̈çlük çek-, hastalık çek-, ızdırap çek-, kahrın çek-, nazını çek-, sıkıntı çek-, zahmet çek- birleşik fiilleri yük kavramının metaforik çerçevesiyle kuşatılmıştır. Bu birleşik fiillerdeki olumsuz duygu ve durumları ifade eden kavramlar, yük kavramı vasıtasıyla algılanmaktadır. Bunlara; günahı/vebali boynuna ol-, risk altına gir-, sorumluluk üstlen-, suçu sırtına yükle-, suçun ă̆ırlığını taşı-, töhmet altında kal-/bırak- birleşik fiilleri ilave edilerek Türkiye Türkçesinde OLUMSUZ DUYGU VE DURUMLAR YÜKTÜR şeklinde bir metafor olduğu sonucuna varılmaktadır. Lakoff ve Johnson'ın usulüyle bu metafor şöyle gösterilebilir:

OLUMSUZ DUYGU VE DURUMLAR YÜKTÜR: Ylllardan beri çektiğim acılar beni hayattan usandırmıştı. Risk altına girmeden bu işi halletmenin bir yolu yok mu? Kimseyi töhmet altında bırakmak istemese de içten içe Rıza'nın suçlu olduğunu düşünüyordu. Bu

103 "Farsça'nın en geniş sözlüğü olma özelliğini taşıyan ve alfabetik olarak düzenlenen eserde kelimelerin çoğunda kronolojik sırayla şiir veya nesir örnekleri (şevâhid) verilmiştir” (Kurtuluş 2003: 220c). 
hastalığı senelerden beri çekmekteydi. Başta biraz acemilik çekersin ama sonra alışacağına eminim. Günahı senin boynuna! İşin sefasını sen sürerken cefasııı ben çekiyorum.

3. Anlamca kalıplaşmış veya deyimleşmiş birleşik fiiller, Lakoff ve Johnson'ın metafor kuramiyla artzamanlı olarak incelenebilir. OLUMSUZ DUYGU ve DURUMLAR YÜKTÜR metaforuna malik birleşik fiiller; Köktürkçe, Eski Uygurca ve Karahanlıca devirlerinde O.D.D. + tüşür- (ilez tüşür- gibi), O.D.D.+DA ara kir- (emgekte ara kir- gibi), O.D.D. + kötür- (emgek kötür- gibi), O.D.D. + yüd- (emgek yüd-, vebāl yüd- gibi) yapılarındadır. Harezm Türkçesi, Doğu Türkçesi ve Eski Anadolu Türkçesinde ise O.D.D. + tart- (emgek tart-, renc tart-, zağmet tart- gibi) veya O.D.D. + çek- (cevr çèk-, belā çèk-, intižär çèk- gibi) yapıları öne çıkmaktadır. Lakoff ve Johnson'ın kuramıyla yola çıkarak bunun gibi değişimlerin sebeplerini araştırmak, anlambilim açısından Türkçenin tarihî serüvenini izlemede yeni yollar açabilir.

4. O.D.D. + çek-/tart- yapısının Farsça mukabili olan O.D.D. + keşíden (renc keşíden)'in Firdevsî (ö. 1020) tarafından Farsçada kullanıldığı görülmektedir. Buna karşılık bu yapının Türkçedeki ilk örneğine, Ez-Zemahşerî el-Harezmî (ö. 1144)'nin 1128-1144 yılları arasında kaleme alındığı düşünülen Mukaddimetü'l-Edeb'inde rastlanılmıştır. Türkçeye O.D.D. + çek-/tart- yapısının Farsçanın etkisiyle geçtiği söylenilebilir.

\section{SUMMARY}

Metaphor can be defined as a figure of speech that describes a concept by referring to another concept which has similar characteristics to first one. George Lakoff and Mark Johnson suggested a different theory of metaphor than conventional understanding. In their point of view, metaphor is not an only figure of speech, also a psychological and cognitive mechanism has an impact on perception and behavior. Famous example for their theory is ARGUMENT is WAR metaphor. It can be seen in following sentences:

ARGUMENT IS WAR: Your claims are indefensible. He attacked every weak point in my argument. His criticisms were right on target. I demolished his argument. I've never won an argument with him. You disagree? Okay, shoot! If you use that strategy, he'll wipe you out. He shot down all of my arguments.

Normally, being indefensible, to attack, weak point, target, to demolish, to win, to shoot, strategy, to wipe (someone) out, to shot down are concepts which are related to war. But in everyday language, these concepts are also mentioned with argumentation. It shows that in this language's culture, war is understood by concepts regarding to war. Due to this, someone who born in this culture can see argumentation as a war and behave accordingly.

Lakoff and Johnson's theory of metaphor can be a basis for grammatical inquries in a particular language. In this study, Lakoff and Johnson's theory of metaphor used as a medium to look compound verbs in Turkish in a different way. In Modern Turkish, compound verbs such as derdini aç-, duyguların aç-, ruhunu aç-, yüreğini aç- has metaphorical basis in terms of Lakoff and Johnson's theory. Verb aç- "to open" implies that dert "trouble", duygu "emotion", ruh "soul", yürek "heart" are closed objects. Therefore, it can be said that these compound verbs has a metaphor EMOTIONS/IDEAS ARE CLOSED OBJECTS. If compound verbs in Turkish has a metaphorical basis in terms of Lakoff and Johnson's theory, then metaphors in compound verbs can be researched diachronically and it can create a new research area.

Looking for metaphorical basis of compound verbs and researching every metaphor diachronically requires huge effort which exceeds the limits of just one study. Due to this, in 
this study compound verbs which has NEGATIVE EMOTIONS/SITUATIONS ARE BURDEN metaphor in Old and Middle Turkish are researched. Compound verbs such as acemilik çek-, act çek-, azap çek-, cefa çek-, çile çek-, derdini çek-, eziyet çek-, güçlük çek-, hastalık çek-, ızdırap çek-, kahrın çek-, nazını çek-, sıkıntı çek-, zahmet çek- in Modern Turkish can be expressed as N.E.S. (Negative Emotions/Situations) + çek-. The verb çek- in these compound verbs means "to weigh" and therefore "to bear". Because of this, concepts which expresses negative emotions and situations such as acl "pain", dert "trouble", güçlük "difficulty" are perceived as burden in Modern Turkish.

Compound verb form N.E.S. + çek- can be traced back to Khorezmian-Kipchak Turkish. Before the Khorezmian-Kipchak Turkish period; in the Orkhon Turkish, Old Uyghur and Karakhanid NEGATIVE EMOTIONS/SITUATIONS ARE BURDEN metaphor can be seen in compound verb forms such as N.E.S. + tüşür- (like ilez tüşür-, buij tüşür-), N.E.S.+DA ara kir(like emgeklerinte ara kir-, adasınta tudasinta ara kir-), N.E.S. + kötür- (like emgek kötür-, küçini kötür, vebāl kötür-), N.E.S. + yüd- (like emgek yüd-, vebāl yüd-). Starting from the Khorezmian-Kipchak Turkish period, N.E.S. + çek- and synonym of this form N.E.S. + tart- have became dominant in Turkish. Also, there is no example of N.E.S. + çek-/tart- form in Orkhon Turkish, Old Uyghur and Karakhanid.

First example of N.E.S. + çek-/tart- form in Turkish is seen in Mukaddimetü'l-Edeb which was presumably written between 1128 and 1144 in Khorezmian-Kipchak Turkish period. Starting from Mukaddimetü'l-Edeb, N.E.S. + çek-/tart- form is seen in texts like Codex Cumanicus, Kısâsü'l-Enbiyâ, Muînü'l-Mürîd, Hüsrev ü Şîrîn, Nehcü'l-Ferâdis, Yûsuf Emîrî Divanı, Sekkâkî Divanı, Lutfî Divanı, Hayretü'l-Ebrâr written by Ali Şir Nevâyî, Süheyl ü Nevbahâr, Garibnâme... Examples like emgek tart-, mignet tart-, şeríat yükin tart-, renc tart-, zagimet tart-, zagimet çek-, bí-dād çek-, mecālını tart-, cevr çek-, ġuŝssa çek-, mignnet çek-, riyāzetler ve mücāhedeler tart-, 'ażäb tart-, belā dart-, zagmet dart-, renc ile āh tart-, derd ü mignet tart- can be seen in these textes.

There is a relation between Persian and Turkish on compound verbs. For example, grammatical structures in Persian like äferin hîuānden, dest dāden, ġam horden, intik̄ām keşíden, ķadem zeden are seen in Turkish as äferin oku-, dest bir-, gam yi-, intik̄ām tart-, ķadem ur-. This correspondence is also seen in compound verbs established with N.E.S. + çek-/tart- form. In Persian, equivalent of N.E.S. + çek-/tart- is N.E.S. + keşíden form. Examples for this form are like belā keşíden, renc keşíden, tengíkeşíden, cefā keşíden, cevr keşíden, 'ażäb keşíden. Persian poet Firdevsî (d. 1020) used N.E.S. + keşíden form in one of his verses as renc ü belā keşíden. Despite that, first Turkish example for N.E.S. + çek-/tart- form was from Mukaddimetü'l-Edeb (presumably written between 1128-1144) as emgek tart-, gurbet tart-, işniij yükin tart-. This evidence indicates that Turkish compound verb form N.E.S. + çek-/tart- is borrowed from Persian.

It can be said as a conclusion:

- Turkish compound verbs can be interpreted with Lakoff and Johnson's metaphor theory.

- Compound verbs mentioned above in Modern Turkish can be understood by the metaphor NEGATIVE EMOTIONS/SITUATIONS ARE BURDEN.

- In Orkhon Turkish, Old Uyghur, Karakhanid periods, compound verbs in Turkish which has NEGATIVE EMOTIONS/SITUATIONS ARE BURDEN metaphor, expressed in N.E.S. + tüşür-, N.E.S.+DA ara kir-, N.E.S. + kötür-, N.E.S. + yüd-; but starting from the Khorezmian-Kipchak Turkish period, N.E.S. + çek-/tart- form has became dominant.

- N.E.S. + çek-/tart- is also seen in Persian as N.E.S. + keşíden. First evidence of this form 
in Turkish is from Mukaddimetü'l-Edeb (presumably written between 1128-1144); but in Persian, Firdevsî (d. 1020) used this from earlier than Turkish example. It shows that Turkish compound verb form N.E.S. + çek-/tart- is borrowed from Persian.

\section{Kisaltmalar}

$\begin{array}{ll}\text { AY-A } & =\text { Altun Yaruk, Altıncı Kitap, bkz. Ayazlı } 2012 . \\ \text { AY-Ç } & =\text { Altun Yaruk'tan İki Parça, bkz. Çağatay } 1945 . \\ \text { AY-EÇ } & =\text { Altun Yaruk, Yedinci Kitap, bkz. Çetin } 2012 . \\ \text { AY-G } & =\text { Aç Bars, bkz. Gulcalı 2015. } \\ \text { AY-K } & =\text { Altun Yaruk, bkz. Kaya 1994. } \\ \text { AY-Ö } & =\text { Altun Yaruk, Üçüncü Kitap, bkz. Ölmez 1991. } \\ \text { AY-U } & =\text { Altun Yaruk, Beşinci Kitap, bkz. Uçar 2009. } \\ \text { DKPAM } & =\text { Daśakarmapathāvadānamālā, bkz. Elmalı } 2016 . \\ \text { DLT I } & =\text { Divanu Lügâti't-Türk I, bkz. Dankoff \& Kelly 1982. } \\ \text { DLT II } & =\text { Divanu Lügâti't-Türk II, bkz. Dankoff \& Kelly 1984. } \\ \text { DTS } & =\text { Drevnetyurskiy Slovar, bkz. Nadalyaev vd. 1969. } \\ \text { EDPT } & =\text { An Etymological Dictionary of Pre-Thirteenth-Century Turkish, bkz. } \\ \text { Clauson 1972. } & \\ \text { EÖT-AÖT } & =\text { Edgü Ögli Tigin - Anyıg Ögli Tigin, bkz. Tulum \& Azılı } 2014 . \\ \text { EUDDMKS } & =\text { Eski Uygurca Din Dişı Metinlerin Karşılaştırmalı Sözvarlığı, bkz. } \\ \text { Ayazlı 2016. } & \\ \text { KB } & =\text { Kutadgu Bilig, bkz. Arat 1947. } \\ \text { Maytr. } & =\text { Maytrısimit, bkz. Ş. Tekin 1976. } \\ \text { O.D.D. } & =\text { Olumsuz Duygu veya Durumlar } \\ \text { RIKT } & =\text { Rylands Interlinear Koran Translation, bkz. Eckmann } 1976 .\end{array}$




\section{KAYNAKÇA}

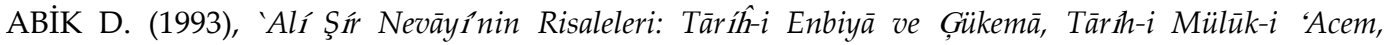
Münşe'ät (Metin-Gramatikal İndeks-Sözlük), c. I, Ankara Üniversitesi, Sosyal Bilimler Enstitüsü, Türk Dili ve Edebiyatı Ana Bilim Dalı, Doktora Tezi, danışman: Prof. Dr. Mustafa Canpolat.

ABİK D. (2004), “Nevâyî'nin Üç Eserindeki Deyimlerin Farsça ile Karşılaştırılması”, Çukurova Üniversitesi Sosyal Bilimler Enstitüsü Dergisi, 13 (1): 211-222.

AKSAN D. (2000), En Eski Türkçenin İzlerinde: Orhun ve Yenisey Yaztllar Üzerinde Sözcükbilim,

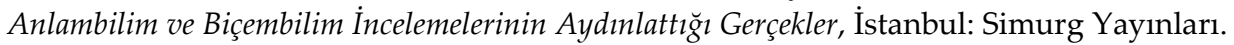

AKÜN Ö. F. (1998), Şemseddin Sâmi - Kâmûs-ı Türk̂̂, İstanbul: Alfa Basım Yayım Dağıtım

AMÎD H. (1374), Ferheng-i Amîd, Tahran: Müessese-i İntişârât-1 Emîr-i Kebîr.

ANDREWS W. G. (1976), An Introduction to Ottoman Poetry, Minneapolis: Bibliotheca Islamica.

ARAT, R. R. (1947), Kutadgu Bilig I: Metin, İstanbul: Milli Eğitim Basımevi.

ARAT, R. R. (1959), Kutadgu Bilig II: Tercüme, Ankara: Türk Tarih Kurumu Basımevi.

ARAT R. R. (1979), Kutadgu Bilig III: İndeks, haz. Kemal Eraslan, Osman F. Sertkaya, Nuri Yüce, İstanbul: Türk Kültürünü Araştırma Enstitüsü Yayınları.

ARAT R. R. (1992), Edib Ahmed b. Mahmud Yükneki: Atebetü'l-Hakayık, Ankara: Türk Tarih Kurumu Basımevi.

ARGUNŞAH, M. \& GÜNER, G. (2015), Codex Cumanicus, İstanbul: Kesit Yayınları.

ATA A. (1997), Nāŝ̀rü̈'d-dín bin Burhānü'd-dín Rabòüzí - Kıısasü'l-Enbiyā (Peygamber Kıssaları), I GirişMetin-Tipkıbasım, Ankara. Türk Dil Kurumu Yayınları.

AYAZLI, Ö. (2012), Altun Yaruk Sudur, VI. Kitap, Karşılaştırmalı Metin Yayını, Ankara: Türk Dil Kurumu Yayınları.

AYAZLI, Ö. (2016), Eski Uygurca Din Dışı Metinlerin Karşılaştırmalı Sözvarlı̆̆ı, Ankara: Türk Dil Kurumu Yayınları.

BANG, W. \& GABAIN, A. (1931), Türkische Turfan-Texte V, Berlin: Verlag Akademie der Wissenschaften in Kommission beiWalter de Gruyter U. Co.

BANG, W., GABAIN, A. \& RACHMATI, G. R. (1934), Türkische Turfan-texte VI. Das Buddhistische Sütra Säkiz Yükmäk, Berlin: Verlag Akademie der Wissenschaften in Kommission beiWalter de Gruyter U. Co.

BERTA, Á. (2010), Sözlerimi İyi Dinleyin... Türk ve Uygur Runik Yazıtlarının Karşllaştırmalı Yayını, çev. Emine YILMAZ, Ankara: Türk Dil Kurumu Yayınları.

CLAUSON G. (1972), An Etymological Dictionary of Pre-Thirteenth-Century Turkish, Oxford: Clarendon Press.

ÇAĞATAY, S. (1945), Altun Yaruk'tan İki Parça: I. Küü Tav'ın canlları öldürdï̈̆̈̈nden dolayı gördüğ̈̈ ceza. II Üç prensle Pars hikâyesi (Prens Maǵasatvi), Ankara: Türk Tarih Kurumu Basımevi.

ÇETIN, E. (2012), Altun Yaruk, Yedinci Kitap, Berlin Bilimler Akademisindeki Metin Parçalarl; Karş̧laştırmalı Metin, Çeviri, Açılamalar, Dizin, Adana: Karahan Kitabevi.

DANKOFF, R. \& KELLY, J. (1982), Maḡmūd al-Kāssigarí, Compendium of the Turkic Dialects (Dŕwān Lugiāt at-Turk), I, Boston: Harvard University Printing Office.

DANKOFF, R. \& KELLY, J. (1984), Mağmūd al-Kāssigarí, Compendium of the Turkic Dialects (Dŕwān Lugiät at-Turk), II, Boston: Harvard University Printing Office.

DANKOFF, R. \& KELLY, J. (1985), Mağmūd al-Kāssigarí, Compendium of the Turkic Dialects （Dŕwān Luġāt at-Turk), III, Boston: Harvard University Printing Office.

DEMIR, G. Y. (2005), George Lakoff-Mark Johnson, Metaforlar: Hayat, Anlam ve Dil, çev. $\quad$ G. Yavuz Demir, İstanbul: Paradigma Yayınları.

DïHHUDÂ, A. E. (1334), Lugâtname, ed. Muhammed Mưîn, Cafer Şehîdî, c. 11， Tahran: Müessese-i Lugatnâme-i Dihhudâ.

ECKMANN, J. (1976), Middle Turkic Glosses of the Rylands Interlinear Koran Translation, Budapest: Akadémiai Kiadó.

ELMALI, M. (2016), Daśakarmapathāouadānamālā (Giriş-Metin-Çeviri-Notlar-Dizin-Tıpkıbaskl), Ankara: Türk Dil Kurumu Yayınları.

ERASLAN K. (1999), Mevlânâ Sekkâkî Divanı, Ankara: Türk Dil Kurumu Yayınları. 
GULCALI, Z. (2015), Eski Uygurca Altun Yaruk Sudur'dan “Aç Bars" Hikâyesi, Ankara: Türk Dil Kurumu Yayınları.

HACIEMINOĞLU, N. (1968), Kutb'un Husrev ü Şirin'i ve Dil Hususiyetleri, İstanbul: Edebiyat Fakültesi Matbaası.

KAÇALIN, M. S. (2011), Niyāzí, Nevâyî̀nnin Sözleri ve Çağatayca Tanıklar: El-Luğātu'n-Nevā'iyye ve'listişhādātu'l-Cağatā'iyye, Giriş-metin-dizinler-tıpkıbaskl, Ankara: Türk Dil Kurumu Yayınları.

KARAAĞAÇ, G. (1997), Lutfì Divanı (Giriş - Metin - Dizin - Tıpkıbasım), Ankara: Türk Dil Kurumu Yayınları.

KAYA, C. (1994), Uygurca Altun Yaruk; Giriş, Metin ve Dizin, Ankara: Türk Dil Kurumu Yayınları.

KORMUŞİN, İ. V. (2017), Yenisey Eski Türk Mezar Yazıtları: Metinler ve İncelemeler, çev. Rysbek ALIMOV, Ankara: Türk Dil Kurumu Yayınları.

KÖKTEKINN, K. (2007), Yusuf Emirî Divanı (Giriş - İnceleme - Tenkitli Metin - Sözlük Tıpkıbasım), Erzurum: Fenomen Yayınları.

KURTULUŞ, R. (2003), “Lugatnâme”, T.D.V. İslam Ansiklopedisi, c. 27, 220-221.

KUT, G. (2003), 'AlíŞír Nevāyí, Ġarā'ibü's-Ŝ́gar: İnceleme - Karşılaştırmalı Metin, Ankara: Türk Dil Kurumu Yayınları.

LAKOFF, G. \& JOHNSON, M. (1980), Metaphors We Live By, Chicago and London: The University of Chicago Press.

NADALYAEV, V. M., NASILLOV, D. M., TENIŞEV, E. R. \& ŞERBAK A. M. (1969), Drevnetyurskiy Slovar, Leningrad: Akademia Nauk SSSR.

ODA, J. (2015), A Study of the Buddhist Sūtra called Säkiz Yükmäk Yaruq or Säkiz Törlügin Y Yarumïs̆ in Old Turkic, Turnhout: Brepols Publishers.

OLGUN T. (1936), Edebiyat Lügati, İstanbul: Âsâr-1 İlmiye Kütüphanesi Neşriyatı.

ÖLMEZ, M. (1991), Altun Yaruk III. Kitap (=5. Bölüm), Ankara: Odak Offset.

ÖZBAY, B. (2014), Huastuanift: Manihaist Uygurlarm Tövbe Duası, Ankara: Türk Dil Kurumu Yayınları.

ÖZYETGIN, A. M. (1996), Altın Ordu, Kırım ve Kazan Sahasına Ait Yarlık ve Bitiklerin Dil ve Üslûp Incelemesi (Inceleme-Metin-Tercüme-Notlar-Dizin-Tıpkıbasım), Ankara: Türk Dil Kurumu Yayınları.

SABİR, M. (2016), Alî Şîr Nevâŷ̂̀ - Hayretü'l-Ebrâr (Karşılaştırmalı Metin), yayına haz. Prof. Dr. Tanju SEYHAN, İstanbul: Kesit Yayınları.

SARAÇ, M. A. Y. (2000), Klâsik Edebiyat Bilgisi-Belâgat, İstanbul: R Yayınları.

SEYHAN, T. (2016), Alî Şîr Nevâŷ̂ - Hayretü'l-Ebrâr (Alfabetik Sözlük - Dizin), İstanbul: Kesit Yayınları.

STEINGASS, F. (1977), Persian-English Dictionary, Including the Arabic Words and Phrases $\quad$ to be met with in Persian Literature, London: Routledge \& Kegan Paul.

ŞÜKUN, Z. (1984), Farsça-Türkçe Lûgat: Gencinei Güftar, Ferhengi Ziya, İstanbul: Milli Eğitim Basımevi.

TARLAN, A. N. (1947), Edebî San'atler, İstanbul: Bürhaneddin Erenler Matbaası.

TEKİN, Ş. (1960), Kuanşi İm Pusar (Ses İşiten İlâh), Vap guna ki atlig nom çeçeki sudur

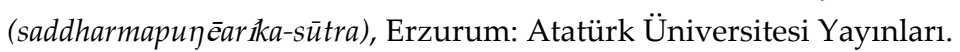

TEKİN, Ş. (1976), Maytrısimit, Burkancıların Mehdîsi Maitreya ile Buluşma, Uygurca İptidâ̂ Bir Dram (Burkancılı̆̆ın Vaibhāŝika tarikatine âit bir eserin Uygurcası), Ankara: Sevinç Matbaası.

TEKIN, T. (1994), Tunyukuk Yazıtı, Ankara: Simurg Yayınları.

TEKIN, T. (2008), Orhon Yazıtları, Ankara: Türk Dil Kurumu Yayınları.

TEKIN, T. (2013), Makaleler II: Tariĥ̂ Türk Yazı Dilleri, hzl. Emine YILMAZ, Nurettin DEMIR, Ankara: Türk Dil Kurumu Yayınları.

TEZCAN, S. \& ZÜLFIKAR, H. (2014), Mahmut b. Ali - Nehcü'l-Ferādís, Uştmaĥhlarnıij Açuq Yolı (Cennetlerin Açık Yolu), Metin, Dizin-Sözlük, Tıpkıbasım, tıp. bas. çeviriyazı Janos Eckmann, diz.söz. Aysu Ata, Ankara: Türk Dil Kurumu Yayınları.

TOPARLI, R. \& ARGUNŞAH, M. (2014), Mu'înü'l-Mürîd, İslâm, İnceleme-Metin-Çeviri-DizinTıpkıbasım, Ankara: Türk Dil Kurumu Yayınları.

TULUM, M. M. \& AZILI, K. (2015), Eski Uygurca Edgü Ögli Tigin Anyıg Ögli Tigin (İyi Niyetli Şehzade - Kötü Niyetli Şehzade), Burkancı Seyirlik Eser, İstanbul: Doğu Kütüphanesi. 
TÜRK DİL KURUMU (1965), XIII. Yüzyıldan Beri Türkiye Türkçesiyle Yazılmış Kitaplardan Toplanan Tanıklarılla Tarama Sözlüğ̈̈, II C - D, Ankara: Türk Tarih Kurumu Basımevi.

UÇAR, E. (2009), Altun Yaruk Sudur V. Kitap, Berlin Koleksiyonundaki Fragmanlarm Transliterasyonu ve Transkripsiyonu, Açıklamalar ve Dizin, İzmir: Ege Üniversitesi, Sosyal Bilimler Enstitüsü, Türk Dünyası Araştırmaları Ana Bilim Dalı, Türk Dili ve Lehçeleri Bilim Dalı, Yayımlanmamış Doktora Tezi.

YILDIRIM, T. (2010), Hüseyin Baykara Divânı (İnceleme-Metin-Dizin-Tıpkıbasım), İ̇stanbul: Hat Yayınevi.

YUNUSOĞLU, M. K. (2016), Budist Türk Çevresi Eserlerde Metaforlar, Ankara: Türk Dil Kurumu Yayınları.

YÜCE, N. (2014), Ebu'l-Ķāsım Cārullāh Mağmūd Bin 'Omar Bin Muğammed Bin Ağmed Ez-Zamaḩ̧̧arí El-Hvārizmí, Mukaddimetü'l-Edeb, Ĥ̃ōrizm Türkçesi ile Tercümeli Şuşter Nüshası: Giriş, Dil Özellikleri, Metin, İndeks, Ankara: Türk Dil Kurumu Yayınları.

ZAJACZKOWSKI, A. (1961), Najstarsza Wesja Turecka, Ĥusräv u Šírín Qušba, Cześć III, Slownik, Warszawa: Panstwowe Wydawnictwo Naukowe. 